\title{
In-Vitro Studies of Bio-Silver Nanoparticles in Cytotoxicity and Anti- Inflammatory
}

\author{
Sneha Paul ${ }^{1 *}$, Sheela Sasikumar $\mathrm{C}^{1}$ and Manickam Dakshinamoorthi B ${ }^{2}$ \\ ${ }^{1}$ Department of Cellular \& Molecular Biochemistry, University of Madras, India \\ ${ }^{2}$ CAS in Botany, University of Madras, Guindy Campus, India
}

Submission: February 01, 2017; Published: August 28, 2018

*Corresponding author: Sneha Paul, Department of Cellular \& Molecular Biochemistry, Frontier, Mediville (Affiliated to University of Madras), Chennai, Tamil Nadu, India, Email: snehapaul_13july@yahoo.com

Keywords: Studies of Bio-Silver; Nanoparticles; Cytotoxicity; Anti- Inflammatory; Amphitheatre; nanotechnology; nanoproducts

\section{Introduction}

Nowadays, nanotechnology is a most promising amphitheatre for generating new applications in biotechnology and Nanomedicine [1]. Among several nanoproducts, a most prominent nanoproduct is nano silver. Silver nanoparticles (AgNPs) have become increasingly popular as an antibiotic agent in textiles and wound dressings, medical devices and appliances, such as refrigerators and washing machines [2]. AgNPs have been used for antimicrobial, antifungal, antioxidant, anticancer, and anti-inflammatory effects [3].

Green chemistry/Green synthesis is the design of chemical products or process that minimize the use hazardous chemical products and eliminate the environmental pollution. Therefore, green synthesis of metallic nanoparticles from biological sources instead of any other chemical products and from different methodologies is the promising and challenging field. Due to this reason, biological method has been prepared not only that it's simple but cost effective too.

In several reports it is reported biological synthesis of silver nanoparticles by plants and their antimicrobial studies, but here the divergent attitude of mycosynthesis of silver nanoparticles by mushrooms, especially medicinal mushroom such as Ganoderma lucidum and their anti-inflammatory and cytotoxicity studies.

Several diversity of naturally occurring mushrooms is found to have promising antioxidant and anticancer properties and prolong the longevity [4]. Mushrooms are mostly known to have anti-inflammatory, cardiovascular, antitumor, antiviral, antibacterial, hepatoprotective and hypotensive activities in biological systems [5-7]. Studies in the edible and medicinal mushroom has revealed lots of beneficial therapeutic properties of them. In our study Ganoderma lucidum (Fr.) Karst. (Ganodermataceae),basidiomycetous fungi, has been widely used for the general promotion of health and longevity in Asian countries for centuries [8]. This edible mushroom was considered to preserve the human vitality and to promote longevity not only that the dried powder of mushroom was used as a cancer chemotherapy agent in ancient China [9]. In addition, Ganoderma lucidum has been used to treat various other disorders such as allergy, arthritis, bronchitis,gastric ulcer, hyperglycemia, hypertension, chronic hepatitis, hepatopathy, insomnia, nephritis, neurasthenia,scleroderma, inflammation, and cancer [10-14].

\section{Materials and Methods}

\section{Extraction of mushroom extract}

Ganoderma lucidum mushroom obtained was washed several times with deionized water.

$68 \mathrm{~g}$ of finely blended sample was boiled for $2-5 \mathrm{~min}$ in $300 \mathrm{~mL}$ water and filtered. The filtrate is cooled to room temperature and used as reducing agent and stabilizer [15].

\section{Synthesis of AgNPs}

$35 \mathrm{mg}$ AgNO3 is dissolved in $250 \mathrm{~mL}$ water. To obtain silver colloids $6 \mathrm{ml}$ of mushroom was added in $30 \mathrm{ml}$ of AgNO3 solution. The formation of $\mathrm{Ag}$ nanoparticles is indicated by light yellowbrown colour and the reduction is completed in $30 \mathrm{~m}$. The formation of nanoparticles was examined under UV-visible spectrophotometer [15].

\section{Characterization of the nanoparticles}

The particle was characterized by UV-visible studies for preliminary confirmation, and the particles were subjected to HR-TEM studies for their size determination, EDAX to determine the percentage of metals present and XRD was done for determination of size and crystalline nature.

\section{Human ethic clearance}

All procedures involving human samples were strictly conducted in accordance with approved guidelines by 
the Institutional Human Ethics Committee (Ref No: FLL/ IEC/04/2014) by Frontier Lifeline Hospital - Institutional Ethics Committee (Ref: FLLH-IEC, Reg No: ECR/200/INST/TN/2013) and in accordance to the regulatory guidelines prescribed by Ethical Guidelines for Biomedical Research on Human participants, ICMR, 2006; Good Clinical Practice \& Guidelines for Clinical Trials on Pharmaceutical products in India, CDSCO, DGHS, MoHFW, Govt of India, including Schedule Y 2005 and its revisions.

\section{In-vitro anti-inflammatory}

\section{Membrane Stabilization assay}

Preparation of haemoglobin rich red blood cells suspension: The blood was collected from healthy human voluntary who has not taken any NSAIDs (Non steroidal antiinflammatorry drugs ) for two weeks prior to the experiment and transferred to the centrifuge tubes.It was centrifuged at $3000 \mathrm{rpm}$ for $10 \mathrm{~min}$ and were washed three times with equal volume of saline.The volume of the blood was measured and reconstructed with $10 \%$ V/V suspension with normal saline [16-18].

Heat induced haemolysis assay: The reaction mixture $2 \mathrm{ml}$ (Sample A and sample B ) consisted of $1 \mathrm{ml}$ of test sample of different concentration $(1.4,4.32,8.64,12.9,14.4,21.6 \mathrm{mg} / \mathrm{l})$ and $1 \mathrm{ml}$ of $10 \%$ hRBCs suspension ,instead of test sample only saline was added to the control test tube.Aspirin $(100 \mu \mathrm{g} /$ $\mathrm{ml}$ ) was used as standard drug.All the test tube containing reaction mixture was incubated in water bath at $56{ }^{\circ} \mathrm{C}$ for 30 minutes.After the incubation,it was cooled for $5 \mathrm{~min}$. Then the reaction mixture was centrifuged at $2500 \mathrm{rpm}$ for $5 \mathrm{~min}$ and the absorbance of the supernatant was taken at $560 \mathrm{~nm}$ using UVVis spectrophotometer $[19,20]$. The experiment was performed in triplicates and percentage inhibition of haemolysis was calculated as follows;

\section{Percntage inhibition $=($ Abs control - Abs Sample $) X 100 /$ Abs control}

Hypotonicity induced haemolysis assay: The reaction mixture 3ml (Sample A and B) consisted of $0.5 \mathrm{ml}$ of different concentration $(1.4,4.32,8.64,12.9,14.4,21.6 \mathrm{mg} / \mathrm{l})$ and $2 \mathrm{ml}$ of hyposaline, $0.5 \mathrm{ml}$ hRBCs suspension,in control test tube instead of test sample $0.5 \mathrm{ml}$ of phosphate buffer was added.Diclofenac sodium $(100 \mu \mathrm{g} / \mathrm{ml})$ was used as standard drug. All the test tube were incubated at $37{ }^{\circ} \mathrm{C}$ for 30 minutes and centrifuged at 3000 rpm for 10 min. The absorbance of supernatant was taken at $560 \mathrm{~nm}$ using UV-Vis spectrophotometer [21]. The percentage inhibition of haemolysis was calculated as follows;

$$
\text { Percntage inhibition }=(\text { Abs control }- \text { Abs Sample }) X 100 / \text { Abs control }
$$

\section{Protein denaturation}

Inhibition of Albumin denaturation: The equal amount of $3 \mathrm{ml}$ reaction mixture $(0.2 \mathrm{ml}$ egg albumin $+2.8 \mathrm{ml}$ phosphate buffer saline) was added to different concentration of test sample and make up the $2 \mathrm{ml}$ of distilled water. In control test tube instead of test sample, PBS was added.Aspirin $(100 \mu \mathrm{g} / \mathrm{ml})$ was used as standard drug. All the test tube were incubated at $370 \mathrm{C}$ for 15 minutes and incubated at $70^{\circ} \mathrm{C}$ for 10 minutes. The samples were cooled for 5 minutes and absorbance was noted at $660 \mathrm{~nm}$ using UV-Vis spectrophotometer [22]. The percentage inhibition of albumin denaturation was calculated as follows;

\section{Percntage inhibition $=($ Abs control - Abs Sample $) X 100 /$ Abs control}

Inhibition of BSA denaturation: The equal amount of $450 \mu \mathrm{l}$ BSA $(1 \mathrm{mg} / \mathrm{ml})$ was added in different concentration $(10,30,60,90,120,150 \mu \mathrm{l} / \mathrm{ml})$ of test samples and made up into $1 \mathrm{ml}$ of distilled water. All the rest of steps were followed according to the albumin denaturation [22].

\section{Percntage inhibition $=($ Abs control - Abs Sample $) X 100 /$ Abs control}

Proteinase inhibition assay: The test followed according to the modified method of [21]. The reaction mixture $(2 \mathrm{ml})$ containing $6 \mu \mathrm{l}$ trypsin, $1 \mathrm{ml}(20 \mathrm{mM})$ tris $\mathrm{HCl}$ and along with different concentration of test samples.The mixture was incubated at $37^{\circ} \mathrm{C}$ for $5 \mathrm{~min}$ after that $1 \mathrm{ml}$ of $0.8 \%(\mathrm{w} / \mathrm{v})$ casein was added. The mixture was incubated again for $20 \mathrm{~min}, 2 \mathrm{ml}$ (70\%) perchloric acid was added to arrest the reaction. Cloudy suspension was observed,it was centrifuged for $5 \mathrm{~min}$ and the supernatant was read at $210 \mathrm{~nm}$ using UV-Vis spectrophotometer. Control was run as same procedure but instead of test sample PBS was suspended [21]. The percentage of inhibition of antiprotienase was calculated as follows;

\section{Percntage inhibition $=($ Abs control - Abs Sample $) X 100 /$ Abs control}

\section{HET- CAM assay}

Pellet preparation: $7.25 \mathrm{mg}$ sodium dodecyl sulfate was dissolved with or without concentration of chitosan and sacchachitosan transdermal films in $1 \mathrm{ml}$ of agarose solution. $10 \mu \mathrm{l}$ of gelling solution was used for pellet preparation.

Incubation [22,23]: The fertile hen eggs were incubated for $75 \mathrm{~h}$ at $37^{\circ} \mathrm{C}$ and relative humidity of $80 \%$.The eggs were kept in horizontal position and rotated several times. Then open snub end after aspiration of $10 \mathrm{ml}$ of albumin from hole. Eggs were traced with scalpel and thereafter the shells were removed with forceps. One pellet per egg was put on newly formed chorio-allanthoic membrane, agarose pellet without SDS acts as negative control, agarose pellet with SDS acts as positive control and agarose pellet with SDS and tested sample acts as treatment. The aperture was covered with parafilm and eggs were returned into the incubator for $24 \mathrm{~h}$ of incubation.

Interpretation [24]: The inhibition or membrane irritation was observed. Positive control egg, exist if the irritation of membrane induced by SDS. Negative control egg, exist no irritation of membrane. Treated group egg, exist various irritation according to concentrations used.

Three irritation reactions such as hemorrhage, lysis and coagulation were monitored and image was taken with the help of SONY 14.1megapixels video camera at $35 \mathrm{~cm}$ above CAM. Time was recorded in seconds, from addition of SDS until the 
appearance of three irritation reaction.

Calculation [25,26]: Irritation index was calculated using following e equation.

$$
\mathbb{R}=300 \times(\mathbb{R})=5 \times(301-T H)+7 \times(301-I L)+9 \times(301-T C)
$$

Time (T) of hemorrhage (H), lysis (L), and coagulation (C) during a period of observation of 300 seconds. IR can take values between 0 and 21 .

Relationship of starting irritation reaction was denoted by $H^{\prime}$, L', and C'.

$$
\begin{aligned}
H^{\prime} & =T H / T H-S D S \\
L^{\prime} & =T L / T L-S D S \\
C^{\prime} & =T C / T C-S D S
\end{aligned}
$$

\section{Antioxidant assay}

DPPH assay: The free radical scavenging activity of the fraction was measured in vitro by 1,1-diphenyl-2-picrylhydrazyl (DPPH) assay.About $0.3 \backslash \mathrm{mM}$ solution of DPPH in ethanol was prepared and $1 \mathrm{ml}$ of this solution was added to $3 \mathrm{ml}$ of the fraction dissolved in ethanol at different concentration.The mixture was thoroughly mixed,incubated at RT for 30 minutes.Then the reading was taken at $517 \mathrm{~nm}$ using UV-Vis spectrophotometer [27]. Ascorbic acid was used as standard drug.The percentage of inhibition of DPPH was calculated as follows;

\section{Percntage inhibition $=($ Abs control - Abs Sample $) X 100 / A b s$ control}

Lipid peroxidation assay: Liver was obtained and homogenized using phosphate buffer. Reaction mixture I consists of $1 \mathrm{ml}$ liver homogenized(10\% W/V),1 ml different concentration of test sample.Lipid peroxidation was induced by $100 \mu \mathrm{l}(15 \mathrm{mM})$ ferrous sulphate.Its incubated for 30 minutes at RT. $0.1 \mathrm{ml}$ reaction mixture II ( $1 \%$ SDS \& $0.1 \%$ thiobarbutric acid) added to all test tube and made up to $1 \mathrm{ml}$ with distilled water and incubated for 1 hour at $95^{\circ} \mathrm{C}$, After butanol and pyridine was added in the ratio $2: 1$. The reaction was mixed thoroughly and centrifuged at $3000 \mathrm{rpm}$ for 15 minutes to separate the layers. Organic layer was separated and read at $530 \mathrm{~nm}$ using UV-Vis spectrophotometer [28]. The percentage of inhibition of lipid peroxidation was calculated as follows;

Percntage inhibition $=($ Abs control - Abs Sample $) X 100 /$ Abs control

\section{Cytotoxicity assay}

Cell Line and Culture Conditions: Vero and HeLa cell line were purchased from the virology dept of king's institute,Guindy,chennai . The cancer cell line was maintained in RPMI-1640 culture medium supplemented with $10 \%$ fetal bovine serum, $100 \mu \mathrm{g} / \mathrm{ml}$ penicillin and $100 \mu \mathrm{g} / \mathrm{ml}$ streptomycin in a $5 \%$ carbon dioxide $\left(\mathrm{CO}^{2}\right)$ cell incubator at $37^{\circ} \mathrm{C}$.

MTT assay: The 3-(4, 5-dimethylthiazol-2-yl)-2, 5-diphenyltetrazolium bromide dye reduction assay was performed to determine the cytotoxic effect of the AgNPs at various concentrations. The assay depends on the reduction of
MTT by mitochondrial dehydrogenase, an enzyme present in the mitochondria of viable cells, to a blue formazan product. The cell concentration was adjusted to $1 \times 10^{5}$ cells $/ \mathrm{ml}$ and plated onto 96-well flat bottom culture plates with various concentrations of AgNPs. All cultures were incubated for 24 hours at $37^{\circ} \mathrm{C}$ in a humidified incubator. After 24 hours of incubation $\left(37^{\circ} \mathrm{C}, 5 \%\right.$ CO2 in a humid atmosphere), $10 \mathrm{ml}$ of MTT $(5 \mathrm{mg} / \mathrm{ml}$ in PBS) was added to each well, and the plate was incubated for a further four hours at $37{ }^{\circ} \mathrm{C}$. The resulting formazan was dissolved in $100 \mathrm{ml}$ of dissolving buffer (provided as part of the kit) and absorbance of the solution was read at $595 \mathrm{~nm}$ using an Elisa reader. All determinations were carried out in triplicate [29]. Concentrations of AgNPs showing 50\% reduction in cell viability (i.e., IC50 values) was then calculated.

Apoptosis Assay - Ethidium Bromide / Acridine Orange Staining: The cells were stained to assess the level of apoptosis [30]. After the treatment period the cells were trypsinized and isolated. $25 \mu \mathrm{l}$ of cell suspension was mixed with $5 \mu \mathrm{l}$ acridine orange and $5 \mu \mathrm{l}$ of ethidium bromide. $10 \mu \mathrm{l}$ of the mixture was added to frosted glass slides and viewed under fluorescent microscope immediately. Cells were analyzed in fluorescent microscopy under $10 \mathrm{X}$ objective.

\section{Statistical analysis}

Data pertaining to antioxidants and anti-inflammations of silver nanoparticles were expressed as mean \pm SEM, $n=6$ and the data were analyzed by One-way ANOVA using GraphPad Prism version 6.00 for Windows (GraphPad Software, La Jolla California, USA). In all the analysis, $\mathrm{P}<0.05$ was considered as statistically significant.

\section{Results and Discussions}

The study on biological synthesis of silver nanoparticles has been previously reported by us [31]. Further applications and cytotoxicity of synthesized silver nanoparticles has been reported in this work.The synthesis of silver nanoparticles from Ganoderma lucidum was confirmed and characterized by various analytical techniques such as UV-VIS spectroscopy,HR-TEM,ICPOES,XRD,EDAX and SAED (Figure 1-5, Table 1 \& 2 ).

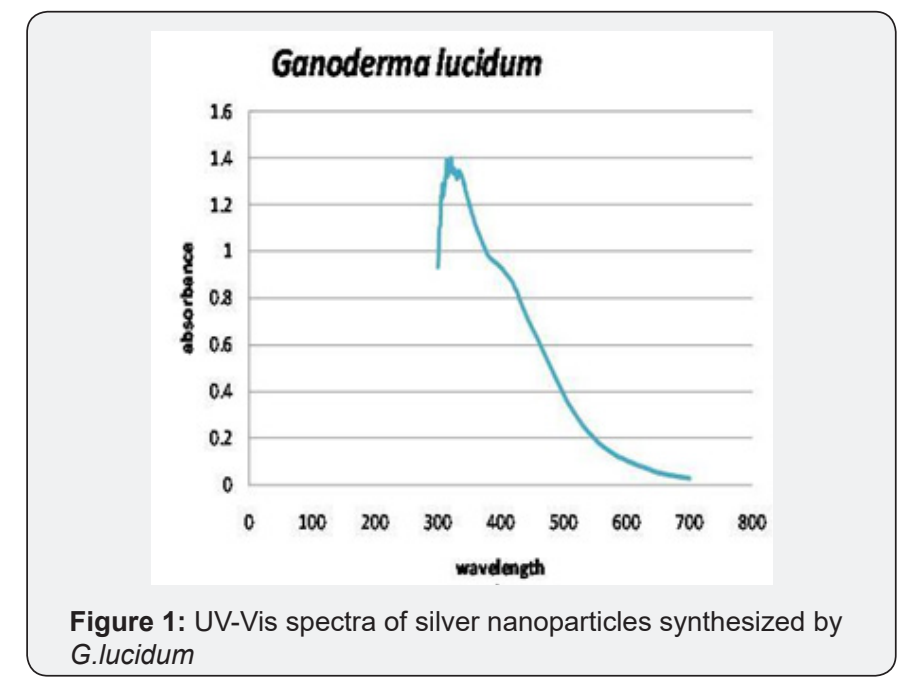




\section{Journal of Complementary Medicine \& Alternative Healthcare}

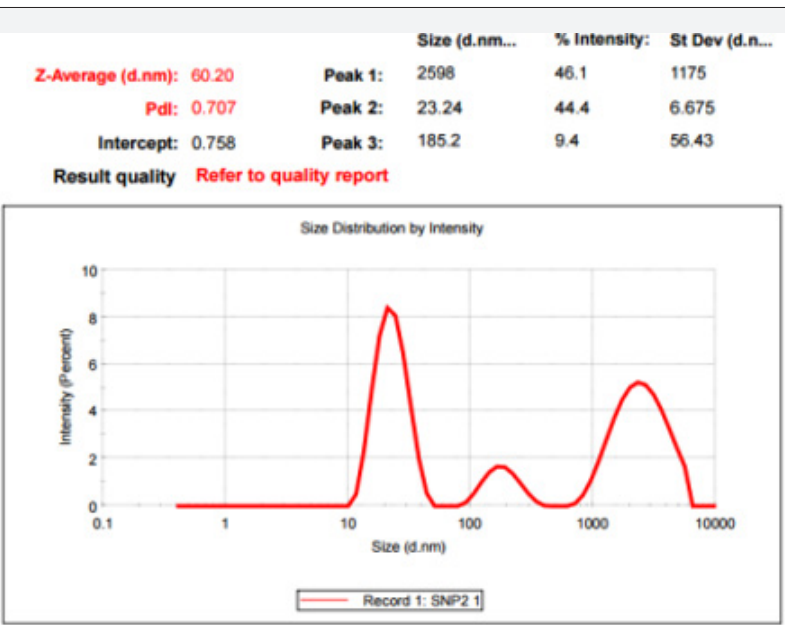

Figure 2: Particle size analysed report of silver nanoparticles.

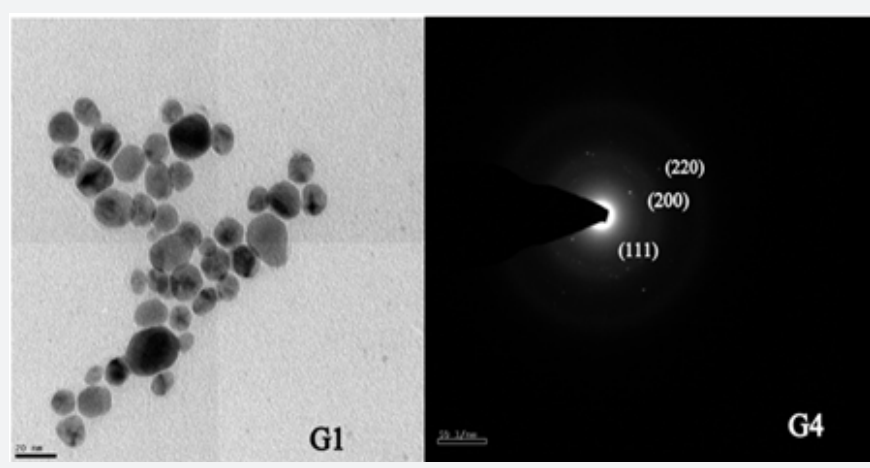

Figure 3: HR-TEM images of SNPs synthesized by G.lucidum.

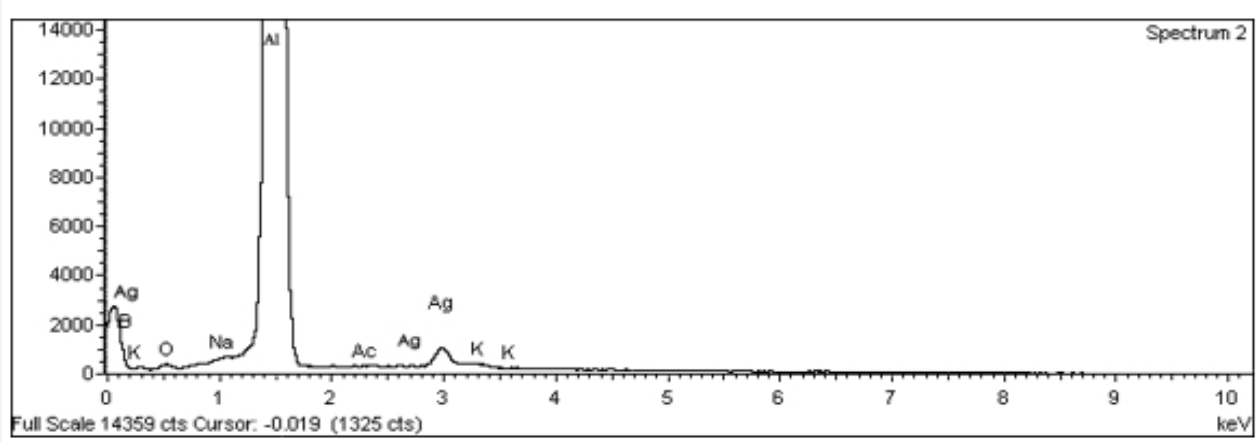

Figure 4: EDAX analysis report.

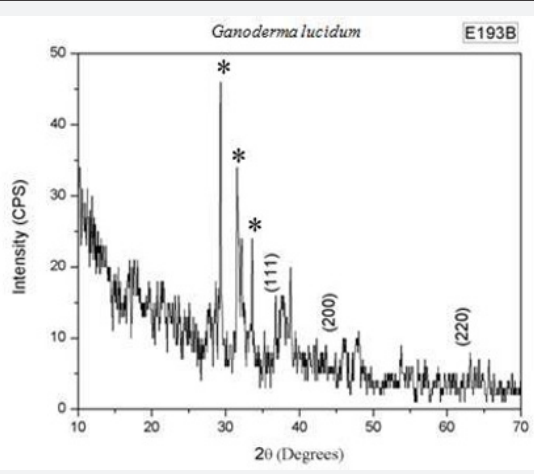

Figure 5: XRD analysis of silver nanoparticles synthesized by G.lucidum. 
Table 1: Presence of various components.

\begin{tabular}{|c|c|c|}
\hline Element & Weight\% & Atomic\% \\
\hline B K & 1.41 & 3.62 \\
\hline O K & 1.37 & 2.37 \\
\hline Na K & 0.15 & 0.19 \\
\hline Al K & 89.45 & 91.71 \\
\hline K K & 0.61 & 0.43 \\
\hline Ag L & 10.11 & 2.57 \\
\hline Ac M & 0.89 & 0.11 \\
\hline Totals & 100 & \\
\hline
\end{tabular}

Table 2: ICP-OES report of silver nanoparticles.

Eample ID
Wavelength $(\mathrm{nm})$

DPPH-std.Ascorbic acid

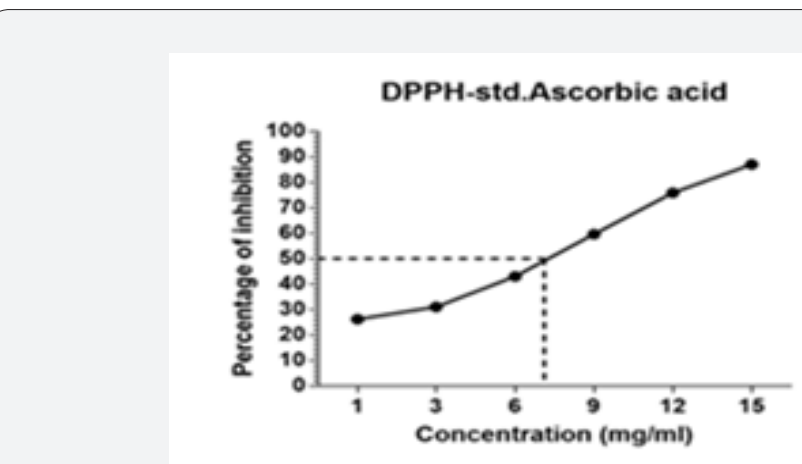

Several concentration ranging from $1 \mathrm{ssmg}$ to $21.6 \mathrm{mg}$ of synthesized silver nanoparticles sample was tested for their antioxidant activity in different in-vitro models. It was observed that free radical scavenged by the sample (standard.Ascorbic acid and tested.Silver nanoparticles) in their unique percentage of inhibition in a concentration dependent manner. Figure 6-7 reveals the reductive capacity of tested samples compared to that of standard [32-35].

In the DPPH method, the antioxidants present in the silver nanoparticles reacts with the stable DPPH (deep violet colour) and converts it into 1, 1 diphenyl-2-picrylhydrazine with discoloration. In the present study, the percentage of inhibition of free radicals at different concentrations ranging from 1-21.6 mg for the tested samples was calculated and compared with the standard ascorbic acid and the results are revealed in Figure 6. This is the common and successfully used method for investigating both hydrophilic and lipophilic antioxidant properties [36-38]. The inhibitory effect (IC-50) follows, SNPs $(9.0 \pm .001 \mathrm{mg} / \mathrm{ml})$ and Std. Ascorbic acid $(7.0 \pm .003 \mathrm{mg} / \mathrm{ml})$ respectively. The prominent results were observed with the Bio-silver nanoparticles that may be due to synergy effect of components such as Ganoderma lucidum and silver nanoparticles comparable to standard ascorbic acid.

Figure 6: DPPH radical scavenging assay.
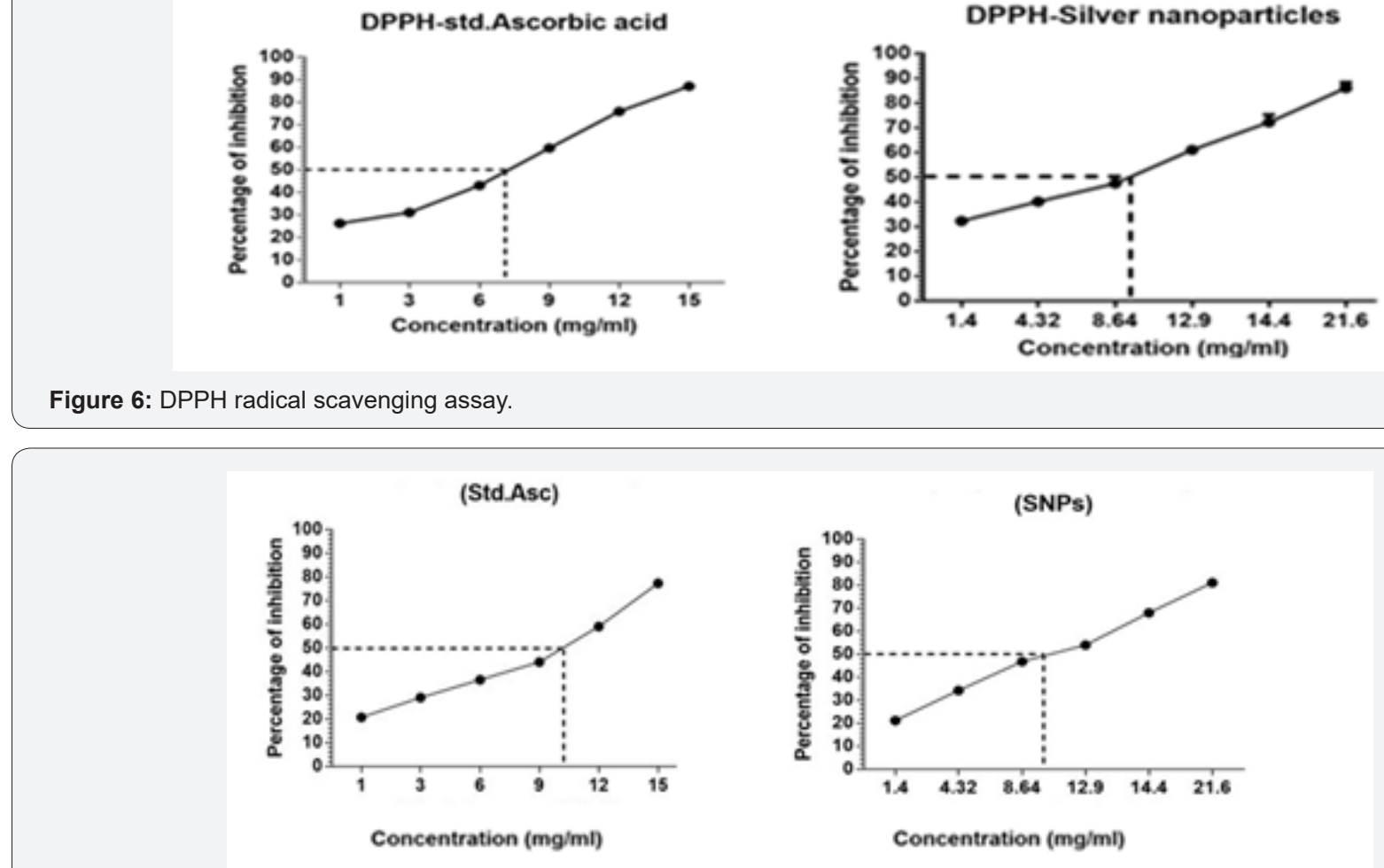

Figure 7: Lipid Peroxidase scavenging assay.

Lipid peroxidation is a critical procedure in free radical pathology as it is cause damage to cells. The liver of hen was utilized as a source of polyunsaturated unsaturated fats for determining the degree of lipid peroxidation [39]. Malondialdehyde is lipid peroxidation product is a pointer of receptive oxygen species (ROS) generation in the tissue 
restraint of lipid peroxide development by tested sample (silver nanoparticles) and standard (ascorbic acid) appeared in Figure 7.

\section{Anti-inflammatory assays}

The HRBC membrane stabilization is one of the techniques followed to study the anti-inflammatory activity. Erythrocytes membrane is closely resemblance of lysosomal membrane $[40,41]$. Furthermore, stabilization of the lysosomal membrane depends on the sample and the concentrate, stabilization of lysosomal membrane is vital in constraining the inflammation response by preventing the release of initiated neutrophil, for example, bacterial proteins and proteases, which creates additional tissue irritation and damage upon extracellular discharge. The enzyme released during response results in various disorder especially with chronic and acute inflammation. The role of drug administrated showed the inhibition and stabilization of lysosomal membrane.

The inhibition of hypotonicity induced HRBC membrane lysis and the stabilization of the membrane by tested sample (silver nanoparticles) and standard sample (Diclofenac sodium) was taken as the measure of anti-inflammatory activity. The percentage of inhibiting lysis of membrane depends on tested sample,it was depended on concentration gradient the tested sample (Silver nanoparticles) were significant $(\mathrm{P}<0.05)$ to that of standard drug and has been illustrated at Figure 8. Silver nanoparticles showed the maximum protection of $58 \%$ at the concentration $21.6 \mathrm{mg}$, whereas diclofenac sodium showed $69 \%$ at the concentration range of $15 \mathrm{mg}$.
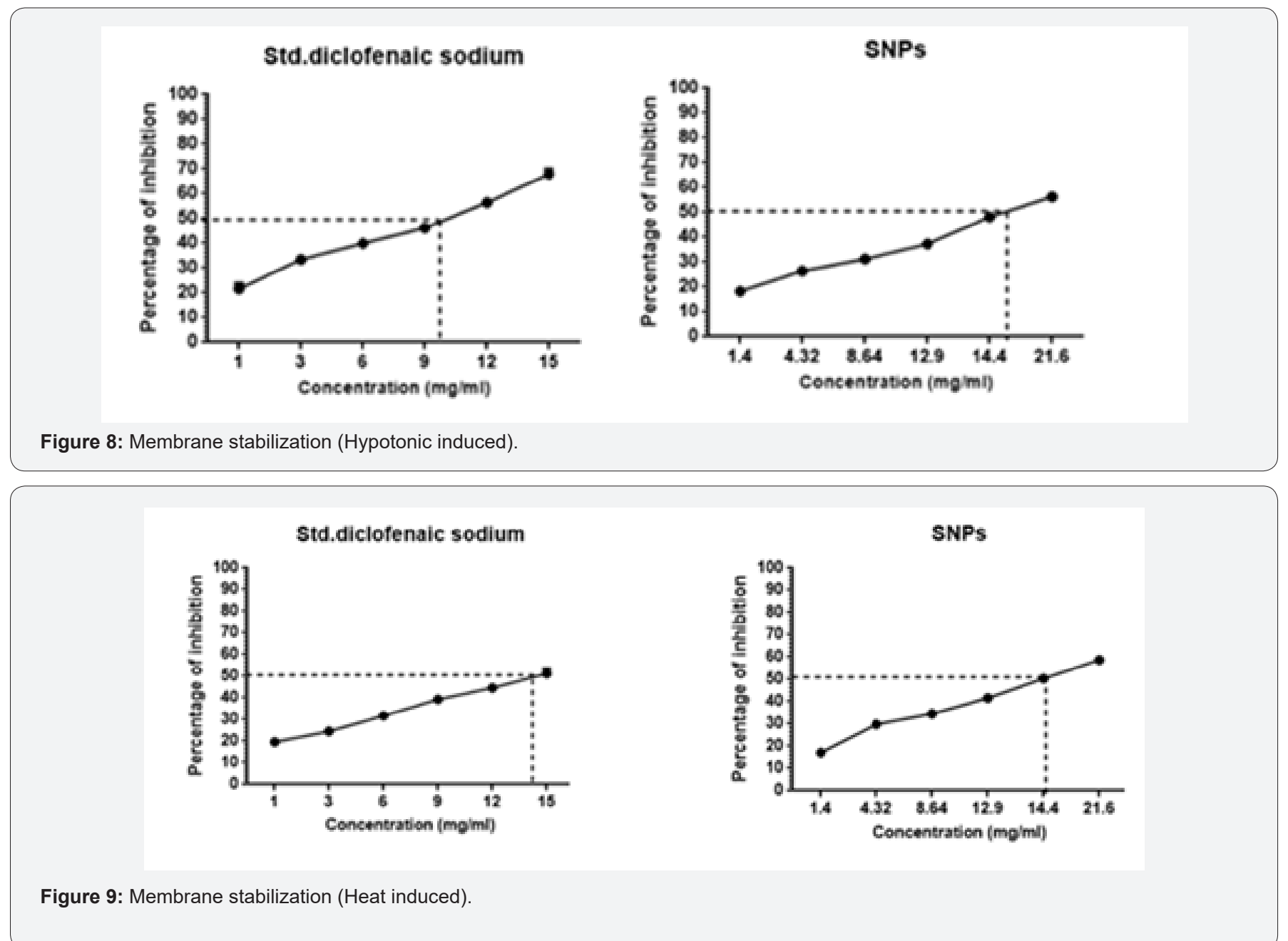

The tested samples were analysed to study the inhibiting reaction against the membrane lysis. From the results observed all the samples along with standard showed a good and statistically significant $(\mathrm{P}<0.05)$ protection of erythrocyte membrane from damage. The detailed report has been analysed and reported at Figure 9.

Protein denaturation is technique in which the protein loses their original form by the external stress or any other chemical compounds [42]. It is one of main cause during the inflammation process. As part of our investigation on the anti-inflammatory mechanism, different concentration of test sample along with standard were checked for the ability of inhibiting protein denaturation. It was effective in inhibiting the protein denaturation; checked with egg albumin and maximum protection was seen in tested sample (sacchachitosan transdermal film) $79.71 \% \& 72.3 \%$ at the concentration range 
of $36.7 \mathrm{mg} / \mathrm{L}$, whereas $50 \%$ of inhibition was seen at range of $1-2 \mathrm{mg} / \mathrm{L}$, other samples shows the maximum inhibition activity such as follows GL;50.1 \& 49.86\% (15mg/ml), SNPs; $70.06 \%$ \& 72.54\% (21.6mg/ml), C; 64.32\% \& 67.63\% (15mg/ml), Sc; $61.8 \& 65.16 \%(15 \mathrm{mg} / \mathrm{ml})$ and CF; $73.24 \& 73.23 \%(32.5 \mathrm{mg} / \mathrm{l})$ compared with std. diclofenac sodium; 61.78 \& 74.32\% (15mg/ $\mathrm{ml}$ ). Each value represented (Figure $10 \& 11$ ) the average mean \pm SEM; $N=6$. All the samples were statistically compared with the standard ${ }^{* * * *} \mathrm{P}<0.001$ considered extremely significant (oneway ANOVA followed by ordinary test was performed using GraphPad Prism version 6).
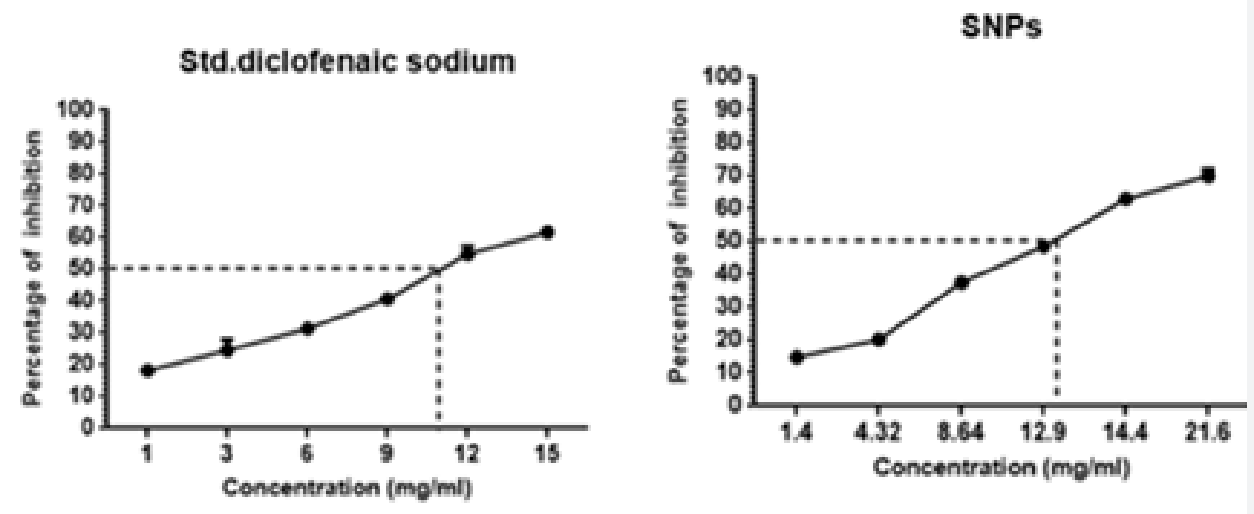

Figure 10: Protein denaturation (Egg Albumin).
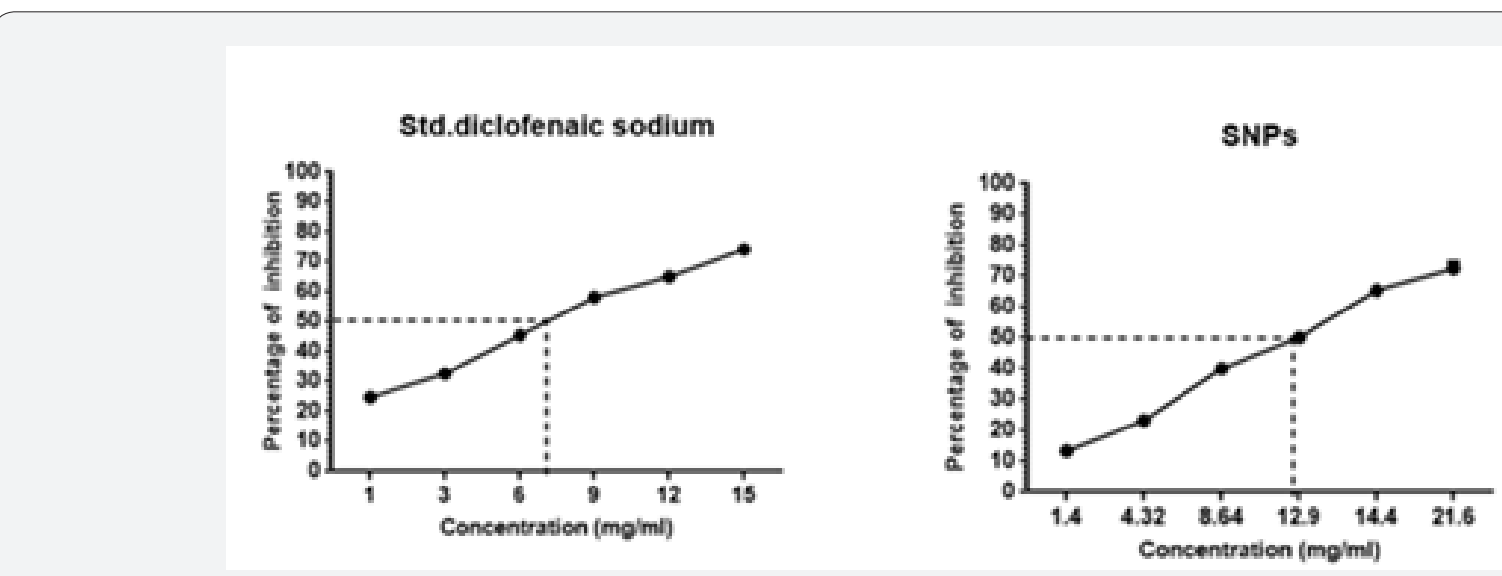

Figure 11: Protein denaturation (BSA).
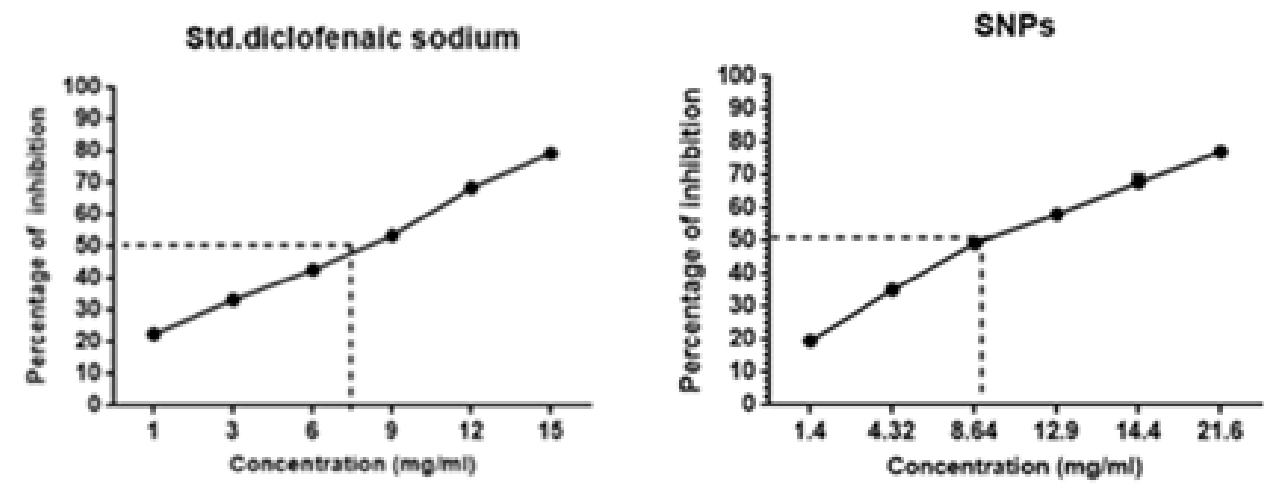

Figure 12: Proteinase inhibiting assay.

Serine proteinase is one of major enzyme released from neutrophils and plays a vital role in the development of tissue damage during inflammation response [43] and significant protection was given by proteinase inhibitors. Samples such as SNPs and standard diclofenaic sodium exhibited significant antiproteinase activity at different concentrations as illustrated in 
Figure 12. Samples showed maximum inhibition of SNPs; $77.18 \%$ $(21.6 \mathrm{mg} / \mathrm{ml})$ and Diclofenac sodium; 74.36\% (15mg/ml). It's significant ${ }^{* * * *} \mathrm{P}<0.001$ with standard (diclofenac sodium).

HET-CAM assay is a unique model to analyse the antiinflammatory role. The two concentrations such as low and high concentration of silver nanoparticles was taken to analyze the role of anti-inflammatory and the membrane irritation resistant. Haemorrhage, lysis and coagulation are the different parameters to be observed during this study.

The inhibitions of irritant reaction in the group of negative control (Induced-SDS) and in the treatment group (silver nanoparticles-SDS) are subjected to chorioallantoic membrane and the changes in CAM was observed and shown at Figure 13. The mean time for the initial irritation reaction in the membrane for each one from tested to control has been calculated and shown (Table 3). From the results; it clearly shows that low concentration gave less irritation compared to higher concentration. There was significant statistical difference between concentrations. Intensive studies of anti-inflammatory analyses are carried by different researchers [44-46] in context with different application. Accordingly, this study has revealed the scientific justification that silver nanoparticles posses antiinflammatory property. Hereby may be taken further for in-vivo wound healing activity Figure 14.

Table 3: Scoring index.

\begin{tabular}{|cccc|} 
Groups & Induced & $\begin{array}{c}\text { Low } \\
\text { concentration }\end{array}$ & $\begin{array}{c}\text { High } \\
\text { concentration }\end{array}$ \\
\hline Irritation Index & $19.06 \pm 1.234$ & $4.24 \pm 1.0222$ & $15.66 \pm 0.874$ \\
\hline
\end{tabular}
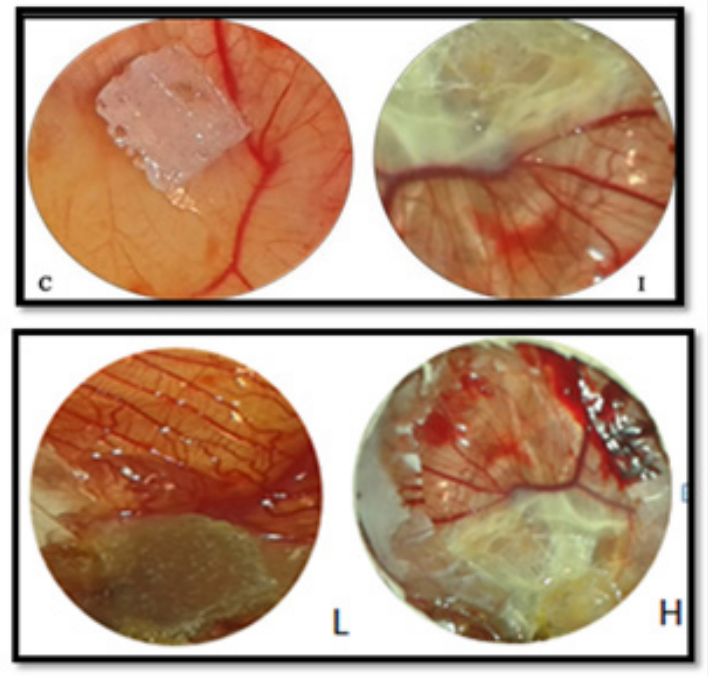

Figure 13: HET-CAM assay.
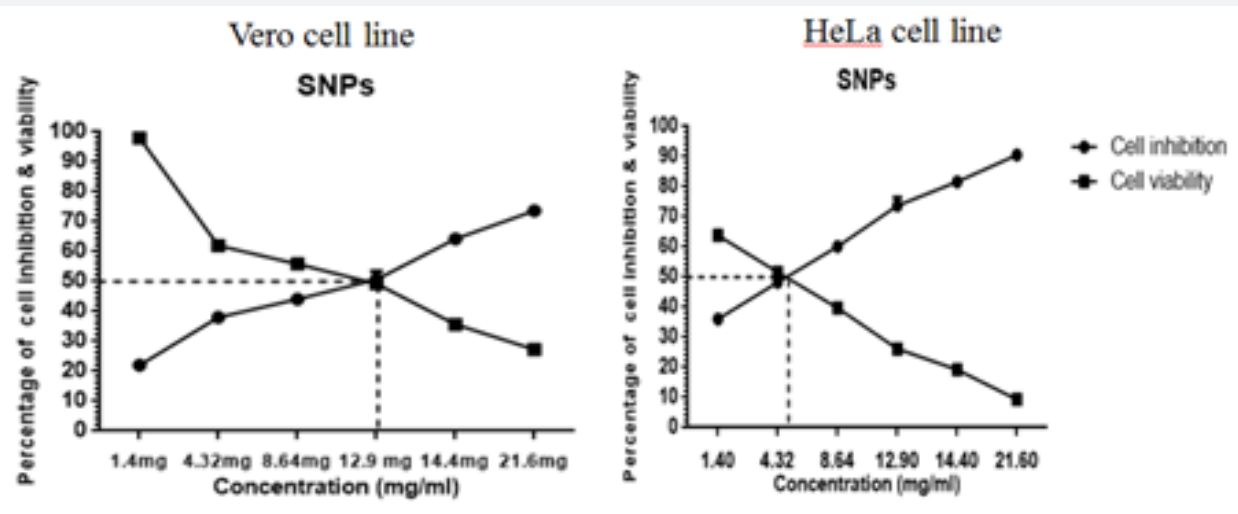

Figure 14: Showing cell viability and cell inhibition in vero and HeLa cell line.

\section{Cytotoxicity assay}

3-(4, 5-Dimethylthiazol-2-yl)-2, 5-diphenyl tetrazolium bromide assay was performed to evaluate the cytotoxicity effect of silver nanoparticles against the African green monkey kidney cell (vero) and cervical cancer cell (HeLa). The different concentrations of samples were used to determine the cell viability after $24 \mathrm{hrs}$ incubation of cells with test samples. The 
cytotoxicity was dependent fully on concentration gradient as the concentration increased mild toxicity was observed at vero but in HeLa cytotoxicity level was higher and viability of cells are lesser (14). The data was analysed by two-way ANOVA followed by paired $\mathrm{T}$ tail test to determine significance difference and correlation between samples. From the results, we have observed that significant $(\mathrm{P}<0.05)$ difference and correlation $(\mathrm{P}>0.05)$ between cell viability and cell inhibition. Similar kind of studies was portrayed by [47], with different extract in to compare toxicity.Further AO-EB staining was performed to analysis the apotosis of cells, IC50 value $(5.10 \pm 0.41 \mathrm{mg} / \mathrm{ml})$ of silver nanoparticles in HeLa cells reveals almost 60\% Figure 15.

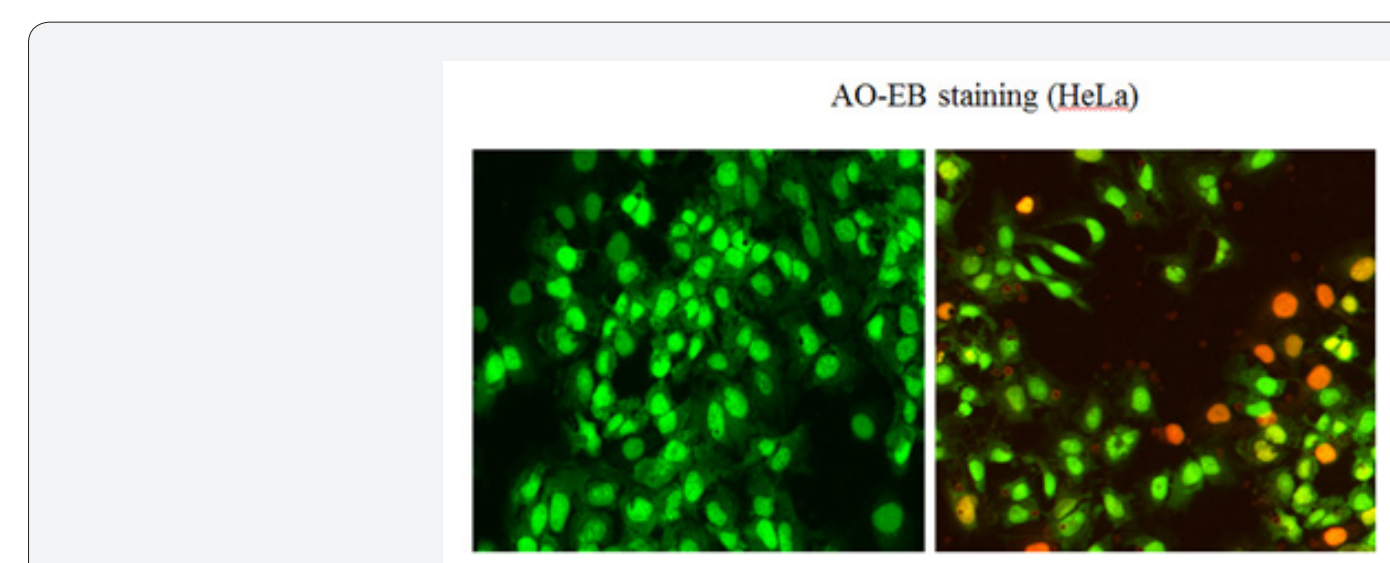

Figure 15: Acridine orange-ethidium bromide dual staining of AgNPs treated HeLa cells.

The apototosis and necrosis property of silver nanoparticles was assesd by IC 50 value against HeLa cells using acridine orange and ethidium bromide dual staining.It was incubated for $24 \mathrm{~h}$ and picture was taken with fluorensce microscope.The treated cells showed early apoptotic cells with the appearance of fluorensce green nuclei due to nuclear fragmentation and chromatin condensation and necrotic cells indicated by orange coloured cells due to the condensation of nuclei; nuclear shrinkage and blebbing.Thus confirming apoptotic activity (see fig ). Similiar kind of results were followed with different cancereous cells [4850]. On comparison, the untreated (control) cells showed green color when stained with AO-EB, indicating their viability nature.

\section{Conclusion}

The outcomes of our research work demonstrated that the biological synthesized silver nanoparticles have indicated less toxicity impact on normal cell line than cancerous cell line and have advocated the ramifications of silver nanoparticles in curing inflammations and tumour suspected afflictions. Additionally this investigation is a bench top model and may be explored further for the anti-inflammatory and wound recuperating application.

\section{Referencers}

1. Chen X, Schluesener HJ (2008) Nanosilver: A nanoproduct in medical application. Toxicol Lett 176(1): 1-12.

2. Stensberg MC, Wei Q McLamore ES, Porterfield DM, Wei A, et al. (2011) Toxicological studies on silver nanoparticles: challenges and opportunities in assessment, monitoring and imaging. Nanomedicine (Lond) 6(5): 879-898.

3. Tian J, Wong KK, Ho CM, Lok CN, Yu WY, et al. (2007) Topical delivery of silver nanoparticles promotes wound healing. Chem Med Chem 2(1): 129-136.
4. Lucas EH, Montesono R, Pepper MS, Ringler RL, Stevens JA, et al. (1957) Tumor inhibitors in Boletus edulis and other holobasidiomycetes. Antibiot Chemother 7(1): 1-4.

5. Wasser SP, Weis AL (1999) Medicinal properties of substances occurring in higher basidiomycetes mushrooms: current perspective (review) Int J Med Mushr 1(1): 31-62.

6. Zhao JD, Zhang XQ (1994) Int Symp Gganoderma Res. Beijing: Bejing Medical University. Resources and taxonomy of Ling Zhi (ganoderma) in China.

7. Liu GT (1991) Recent advances in research of pharmacology and Clinical application of Ganoderma (P. Karst) species (Aphyllophoromycetideae) in China. Int J Med Mushr 1(1): 63-67.

8. Jones S, Janardhanan KK (2000) Antioxidant and antitumor activity of Ganoderma lucidum (Curt.: Fr.) P. Karst-Reishi (Aphyllophoromycetideae) from South India. Int J Med Mushr 2(3): 195-200.

9. Cao QZ and Lin ZB (2004) Antitumor and anti-angiogenic activity of Ganoderma lucidum polysaccharides peptide. Acta Pharmacologia Sinica 25(6): 833-838.

10. El-Mekkawy S, Meselhy MR, Nakamura N, Tezuka Y, Hattori M, et al. (1998) Anti-HIV-1 and anti-HIV-1- protease substances from Ganoderma lucidum. Phytochemistry 49(6): 1651-1657.

11. Fujita R, Liu J, Shimizu K, Konishi F, Noda K, et al. (2005) Anti-androgenic activities of Ganoderma lucidum. Journal of Ethnopharmacology 102(1): 107-112.

12. Tao S, Feng KA (1991) Influence of Ganoderma lucidum on platelet aggregation of 15 healthy volunteers and 33 senile or presenile patients. Acta University Medical Tong Ji 20: 186-188.

13. Stanley G, Harvey K, Slivova V, Jiang J, Sliva D (2005) Ganoderma lucidum suppresses angiogenesis through the inhibition of secretion of VEGF and TGF- $\beta 1$ from prostate cancer cells. Biochemical and Biophysical Research Communications 330(1): 46-52.

14. Gunde-Cimerman N (1999) Medicinal value of the genus Pleurotus (Fr.) P. Karst. (Agaricales S. R., Basidiomycetes). International Journal of Medicinal Mushrooms 1: 69-80. 
15. Sneha Paul, Changam Sheela Sasikumar, Anita RJ Singh, et al. (2015) Preliminary Investigation of Synthesizing Silver Nanoparticles from the Different Biological Source: - A Modern Ecofriendly Tool. International Journal for Pharmaceutical Research Scholars 4(1): 135-148.

16. Sakat S, Juvekar AR, Gambhire MN (2010) In-vitro antioxidant and antiinflammatory activity of methanol extract of Oxalis corniculata Linn. International Journal of pharma and Pharmacological Sciences 2(1): 146-155.

17. Oyedepo 00, Femurewa AJ (1995) Anti-protease and membrane stabilizing activities of extracts of Fagra zanthoxiloides, Olax subscorpioides and Tetrapleura tetraptera. Int J of Pharmacong 33(1): 65-69.

18. Sadique J, Al-Rqobahs WA, Bughaith, EIGindi Ar (1989) The bioactivity of certain medicinal plants on the stabilization of RBS membrane system. Fitoterapia 60: 525-532.

19. Shinde UA, Kulkarni KR, Phadke AS, et al. (1999) Mast cell stabilizing and lipoxygenase inhibitory activity of Cedrus deodara (Roxb.) Loud. Wood Oil. Indian J Exp Biol 37(3): 258-261.

20. Azeem AK, Dilip C, Prasanth SS, Kumsr Sajeev, C Naseera, et al. (2010) Anti-inflammatory activity of the glandular extracts of Thunnus alalunga. Asia Pac J for Med 3(10): 794-796.

21. Mizushima Y and Kobayashi M (1968) Interaction of anti-inflammatory drugs with serum preoteins, especially with some biologically active proteins. Journal of Pharma Pharmacol 20(3): 169- 173.

22. Arcy D, PF, Howard EM (1967) A new anti-inflammatory test, utilising the chorioallantoic membrane of the chick embryo. Br J Pharmac Chemother 29(3): 378-387.

23. Harborne J (1984) Phytochemical Methods. 2nd ed. London, Chapman and Hall.

24. Marchesan M, Paper DH, Hose H (1998) Investigation of anti inflammatory activity of liquid extracts of Plantago lanceolata L. Phytother. Res 12: 33-34.

25. Wilson TD, Steck WF (2000) A modified HET-Cam assay approach to the assessment of anti-irritant properties of plant extracts. Food Chem Toxicol 38(10): 867-872.

26. Luepcke NP (1985) HET-chorioallantois-test: an alternative to the Draizé rabbit eye test. In: Goldberg, A.M. (Ed.), In Vitro Toxicology. New York, USA: Mary Ann Libert Inc. Publishers, pp. 353-363.

27. Blois MS (1958) Antioxidant determinations by the use of a stable free radical. Nature 181: 1199-1200.

28. Bar-Or D, Rael LT, Lau EP, Rao NK, Thomas GW, et al. (2001) An analog of the human albumin N-terminus (Asp-AlaHis-Lys) prevents formation of copper-induced reactive oxygen species. Biochem. Biophys Res Commun 284(3): 856-862.

29. Smith J, Rowan N, Sullivan R (2002) Medicinal Mushrooms. Their Therapeutic Properties and Current Medical Usage with Special Emphasis on Cancer Treatment. Special Report Commissioned by Cancer Research UK, The University of Strathclyde in Glasgow, pp. 256

30. Kasibhatla S, Amarante-Mendes GP, Finucane D, et al. (2006) Acridine Orange/Ethidium Bromide (AO/EB) Staining to Detect Apoptosis. Cold Spring Harbor Protocols 3: 4493.

31. Sneha Paul, Anita RJ Singh, Changam Sheela Sasikumar (2015) Green synthesis of bio-silver nanoparticles by Parmelia perlata, Ganoderma lucidum and Phellinus igniarius \& their fields of application Indian Journal of Research in Pharmacy and Biotechnology 3(2): 100-110.

32. Cordeiro JCR, Reis AO, Miranda EA, The Arbekacin Study Group (2001) In-Vitro Antimicrobial Activity of the Aminoglycoside Arbekacin Tested Against Oxacillin-Resistant Staphylococcus Aureus Isolated in Brazilian Hospitals. Brazilian J Infectious Diseases 5(3): 130-135.
33. Latman NS, Kishore V, Bruot Bc (1994) 16-Epiestriol: An AntiInflammatory Steroid Without Glycogenic Activity. J Pharm Sci 83(6): 874-877.

34. Charrouf $Z$, Guillaume D (2007) Phenols and Polyphenols from Argania Spinosa. American Journal of Food Technology 2(7): 679-683,

35. Park Hy, Toume K, Arai Ma, et al. (2014) A Cardenolide from Calotropis Gigantea that Inhibits Wnt Signaling By Increasing Casein Kinase $1 \alpha$ In Colon Cancer Cells. Chembiochem 15(6): 872-878.

36. Yu L (2001) Free Radical Scavenging Properties of Conjugated Linoleic Acids. J Agric Food Chem 49(7): 3452-3456.

37. Parry J, Su L, Luther M, et al. (2005) Fatty Acid Composition and Antioxidant Properties Of Cold-Pressed Marionberry, Boysenberry, Red Raspberry and Blueberry Seed Oils. J Agric Food Chem 53(3): 566573.

38. Prior R, Wu X, Schaich K (2005) Standardized Methods for The Determination of Antioxidant Capacity and Phenolics in Foods and Dietary Supplements. J Agri Food Chem 53(10): 4290-4302.

39. Sachin S Sakat, Archana R Juvekar, Manoj N Gambhire (2010) InVitro Antioxidant And Antilnflammatory Activity of Methanol Extract of Oxalis Corniculata Linn. International Journal of Pharmacy and Pharmaceutical Sciences 2(1): 146-155.

40. Gandhidasan R, Thamaraichelvan A, Baburaj S (1991) Anti Inflammatory Action Of Lannea Coromandelica By Hrbc Membrane Stabilization. Fitoterapia 9(12): 81- 83.

41. Shenoy S, Shwetha K, Prabhu K, R Maradi, KL Bairyet al. (2010) Evaluation of Anti-Inflammatory Activity of Tephrosia Purpurea in Rats. Asian Pac J Trop Med 3(3): 193-195

42. Leelaprakash G, Mohan Dass S (2011) In-vitro Anti inflammatory Activity of Methanol Extract of Enicostemma Axillare. Int J Drug Dev \& Res 3(3): 189-196.

43. Das SN, Chatterjee S (1995) Long Term Toxicity Study of Art-400. Indian Indg Med 16(2): 117-123.

44. Dary L, Mendoza M, Stephanie Saavedra A (2013) Chemical Composition and Anti-Irritant Capacity of Whole Body Extracts of Ulomoides Dermestoides (Coleoptera, Enebrionidae). Revista De La Facultad De Química Farmacéutica 20(1): 41-48.

45. Adelheid H, Brantner, Fran Quehenberger, Asima Chakraborty, Lutta Polligger, et al. (2002) HET-CAM Bioassay As In Vitro Alternative to The Croton Oil Test For Investigating Steroidal And Non-Steroidal Compounds. Della Loggia altex 19(2): 51-55.

46. Oladimeji HO, Nia R, Offorah E (2007) Anti-Oxidant and AntiInflammatory Activity of Centrosema Pulmieri Benth (LeguminoseaPapilionaceae). Journal of Pharmacology and Toxicology 2(6): 580-585.

47. Senthilraja Kathiresan (2015) In-Vitro Cytotoxicity Mtt Assay in Vero Hepg2 And Mcf -7 Cell Lines Study of Marine Yeast. Journal of Applied Pharmaceutical Science 5(3): 80-84.

48. Pillai JJ, Thulasidasan AKT, Anto RJ, Chithralekha DN, Narayanan A, et al. (2014) Folic acid conjugated cross-linked acrylic polymer (FA-CLAP) hydrogel for site specific delivery of hydrophobic drugs to cancer cells. J. Nanobiotechnology 12: 25.

49. Nair K, Jagadeeshan S, Nair SA, Kumar GS (2011) Biological evaluation of 5fluorouracil nanoparticles for cancer chemotherapy and its dependence on the carrier, PLGA. Int J Nanomedicine 6: 1685-1697.

50. Cui S, Qu X, Xie Y, Zhou L, Nakata M, et al. (2006) Curcumin inhibits telomerase activity in human cancer cell lines. Int J Mol Med 18(2): 227-231. 
This work is licensed under Creative Commons Attribution 4.0 License

DOI: 10.19080/JCMAH.2018.07.555719

\section{Your next submission with Juniper Publishers will reach you the below assets}

- Quality Editorial service

- Swift Peer Review

- Reprints availability

- E-prints Service

- Manuscript Podcast for convenient understanding

- Global attainment for your research

- Manuscript accessibility in different formats

(Pdf, E-pub, Full Text, Audio)

- Unceasing customer service

Track the below URL for one-step submission https://juniperpublishers.com/online-submission.php 